\title{
THE EDUCATIONAL POTENTIAL OF RUSSIAN LANGUAGE AND LITERATURE LESSONS
}

\section{Guzal Sabirzhanovna Atamukhamedova}

Teacher, Department of "Uzbek Language", Tashkent State Transport University, Uzbekistan

Nigora Dzhurakhanovna Izzatullaeva

Teacher, Department of "Uzbek Language", Tashkent State Transport University, Uzbekistan

\section{ABSTRACT}

The author of the article investigated the most important condition for achieving a new quality of education is the improvement of the lesson. The organizational form of the educational process in educational institutions. He also noted in his article that the lesson has unique opportunities to influence the formation of many personality traits.

KEYWORDS:- education, skills, development, formation, educational process, lesson, aspects, personality, theory, practice.

A book is a teacher without pay or gratitude.

Every moment gives you revelations of wisdom".

A. Navoi

I see more and more clearly that the key to everything is in education.

That's the denouement of everything. This is the longest but surest way.

L.N Tolstoy.

\section{INTRODUCTION}

Education is one of the most important components of the educational process along with teaching. Complementing each other, education and upbringing serve a single goal: the holistic development of the student's personality.

The new Law on Education defines upbringing as "an activity aimed at personal development, creation of conditions for self-determination and socialization of the student on the basis of sociocultural, spiritual and moral values and socially accepted rules and norms of behavior in the interests of the individual, family, society and the state.
Here are the key words: development, upbringing, formation.

The most important condition for achieving a new quality of education is the improvement of the lesson - the main organizational form of the educational process in the educational institution.

I believe that educational work should take place primarily in the classroom, not afterwards. And the lesson does not necessarily have to be an educational hour.

The lesson has a unique ability to influence the formation of so many qualities of personality of students. 
CURRENT RESEARCH JOURNAL OF PEDAGOGICS 2(10): 96-100,

October 2021 DOI: https://doi.org/10.37547/pedagogics-crjp-02-10-18

ISSN 2767-3278

(C)2021 Master Journals

\section{Crossref doi) gr Google}

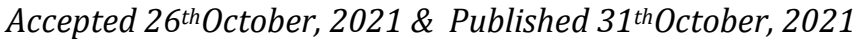

Educational aspect should provide the use of the content of the teaching material, teaching technologies, forms of organization of cognitive activity in their interaction to implement the formation and development of moral, labor, aesthetic, patriotic, environmental and other personal qualities of a schoolchild. It should be aimed at fostering the right attitude to universal values, a high sense of civic duty.

At the lesson we teach, we equip students with the skills to apply knowledge in practice, and the teacher's task is to make this time become a fullfledged moral communication, a thoughtful interaction. The lesson is an extension of the learner's life and a continuation of the formation of his or her personality. Its implementation depends on the purposeful selection of the content of educational material, providing students with examples of genuine morality, patriotism, spirituality, citizenship, humanism. The content of which does not lend itself to formalization and standardization are the lessons of the Russian language and literature. Lessons of the Russian language (as well as any other language and subject) are called to solve the problems of the training defined by the state program, and problems of education of personality of the rising generation in indissoluble unity.

The task of the teacher is not just to teach the child to write vowels and consonants in the root of the word, correctly put punctuation in complex sentences, but also to instill in the student a love for his native language as a national treasure and as a means to ensure the process of personal development.

Education of moral qualities in Russian lessons through the use of literary text is not a tribute to fashion, but a vital necessity. After all, society needs people educated, thinking, with developed thinking, creators, innovators.

Possessing great power of influence, a literary text contributes to the formation of spiritual consciousness, ideas about good and evil, about the place and purpose of man in the surrounding world, develops high feelings. It forces to find for each lesson that text material which contents will help us in formation of citizenship and personal qualities of the pupil.

Practice shows that a lesson in which grammar is studied with informative text material that provides the educational function of the lesson, leaves a deeper impression on the memory of students, and spelling skills formed on it, are usually more conscious and stable, and therefore more durable.

Unfortunately, in recent years interest in literature in society and interest in literature as a school subject has declined catastrophically. Nowadays, literature, which has always been perceived as a source of comprehension of the world, which was commonly called "the textbook of life," is no longer needed, the readership has shrunk considerably.

To live as Russian literature suggests is certainly more difficult, but certainly more worthy...

Unique and unique Russian literature is able to resurrect the concept of "moral person", which includes many spiritual qualities of man: kindness and the ability to sympathize, humanity and responsiveness, conscientiousness and justice, honesty and decency, politeness and tactfulness, responsibility, industriousness, respect for others and their work, compliance with standards of behavior, curiosity - and help solve many moral problems of our time.

Why is she so unique and what is her uniqueness? It is in its view of the meaning of human existence. Russian literature focuses on the portrayal of the human personality and moral and philosophical issues.

Russian writers demand a great deal from people. They do not agree with "people putting 
CURRENT RESEARCH JOURNAL OF PEDAGOGICS 2(10): 96-100,

October 2021 DOI: https://doi.org/10.37547/pedagogics-crjp-02-10-18

ISSN 2767-3278

(C)2021 Master Journals

Crossref doi) $\mathrm{g}^{\prime}$ Google

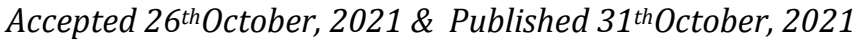

their interests and their selfishness in the forefront."

Literature creates the ethical and aesthetic background against which human behavior is shaped. That is why it must not be withdrawn from life, from school. The teacher of literature must do everything possible and impossible to arouse interest in the subject and revive its importance.

The most important thing in the lesson - to cause an emotional outburst in the souls of children, not to allow the "soul to be lazy". For this purpose, it is possible and necessary to involve such means of influence as music and painting. All this helps to activate the processes of education and moral education. At the lessons one must use teaching methods with a practical orientation, because the introduction of ethical categories must take place in their everyday intertwining, according to the "textbook of life". This develops a desire for moral action.

The methods used in the lessons should be aimed at enabling students to turn to the problem "faceto-face" so that a dialogue could be born between the student and himself, helping to develop selfawareness, self-esteem, personal position, contributing to an in-depth penetration of the problem of a work of fiction.

For example, several techniques:

- five-minute prologues, where students are asked to reflect on an aphorism or a poem of a great man about the problem raised in the work studied at the moment (the material is offered both by the teacher and by students prepared in advance);

- the method of brainstorming, where students are offered to think about parables (old Russian moral genre), little-known, but certainly figurative and bright facts from life, literature and journalism, which are better absorbed and "sink into the soul";
- projection of moral ideas onto students' own lives, taking into account their age (students are encouraged to think about moral choices, make decisions and substantiate their positions).

- projection of moral problems solved by the classics and their evaluation from the standpoint of modern generally accepted standards of behavior: has the attitude toward the norms of human behavior in society changed or is life making changes?

- The use of non-standard lessons (e.g., lessons in concerts where poetry provides fertile material; or lessons in debates, reflections, or discussions of contemporary literature) also fosters interest in the subject;

- The essay as a type of work also shows a person's intellect, horizons, and degree of literacy. In essays of different genres (literary portrait of a character, essay-review essay, essay-essay, essay-poem, essay-diary, essayletter on behalf of a character) students can show their individuality, express their point of view, position, which may differ from the generally accepted.

The teaching of literature helps the younger generation to discover the world, to teach to meet and overcome difficulties, to solve moral problems.

A work of fiction is a kind of bridge between the author and the reader. Understanding the point of view of the writer, revealing the problematic content of the text, the student learns himself. And the teacher is a guide and helper. So, the most important thing for a teacher of literature is to structure the conversation so that the student will happily follow him into the world of literature. Through the educational dialogue of teacher and student there is a cultural, moral and spiritual mutual enrichment of students and teacher. 
CURRENT RESEARCH JOURNAL OF PEDAGOGICS 2(10): 96-100,

October 2021 DOI: https://doi.org/10.37547/pedagogics-crjp-02-10-18

ISSN 2767-3278

(C)2021 Master Journals

\section{Crossref doi) 81 Google}

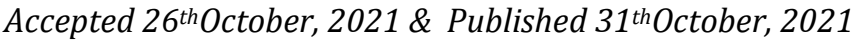

In the center of attention at a modern lesson there is a student, his personality, there is a humanization of process of training, conditions for development of interests and aspirations of students are created, stimulation of realization of their needs and motives, involvement in creative educational work which would bring students pleasure from understanding of the reached, respect to personal advantage both learners, and trainees. The joy of learning, illuminated by success in achieving the goal is the source of inner strength of the child, the inner energy to overcome difficulties and develop a desire to learn.

By this we can say that literature is aimed at finding the best ways to the heart and mind of schoolchildren.

V.A. Sukhomlinsky wrote: "A teacher who is able to educate with knowledge, this knowledge... The teacher who knows how to bring up knowledge acts as a tool for pupils to consciously make new steps in learning the world".

Professionalism of the teacher is not so much in methodical literacy, as in the ability to select the material for the lesson, to determine its educational and pedagogical capabilities. Talent of the teacher - in a subtle feeling of possibilities of the subject in formation of moral, intellectual, volitional, emotional qualities of the person. The content of a school subject in the classroom is a powerful tool to influence the structure of a child's personality. But to make positive changes in this structure can only be that teacher who himself perfectly mastered this tool and understands its educational possibilities.

A.S. Makarenko said, referring to the teachers: "... You have to be able to say so that the students in your words felt your will, your culture, your personality. He pointed out, however, that this had to be learned.

The modern lesson should contribute to the student's personal growth. Every lesson is a step in the development of the creative potential of a schoolchild, his self-knowledge, self-education and self-development.

I also believe that literature and the native language help to answer

What are the main human questions: What is truth? Who am I? Is this how I live? What did I come into this world for? That is, our literature raises just those questions that any thinking teenager is bound to ask himself or herself.

\section{REFERENCES}

1. Gulyakov, E. N. New Pedagogical Technologies: Development of Artistic Thinking and Speech at the Literature Lessons: Methodical Handbook / E.N. Gulyakov. Gulyakov. - M.: Drofa, 2016.

2. Modern lesson of the Russian language and literature / ed. by Z.S. Smelkova. - L.: Nauka, 1990.

3. Chernilevsky D.V. Spiritual and moral values of the educational system of Russia XXI century / D.V. Chernilevsky. - M.: RIO MGTA, 2017.

4. Petrash, I.A. Historical novel as a means of education of a harmonious personality / I.A. Petrash // University complex as a regional center of education, science and culture. Materials of the All-Russian scientific and methodological conference (with international participation); Orenburg State University. - Orenburg: 000 IPK "University", 2013. - C. 17241729

5. Petrash, I.A. Moral education by means of fiction / I.A. Petrash // University Complex as a regional center of education, science and culture. Materials of the All-Russian 
CURRENT RESEARCH JOURNAL OF PEDAGOGICS 2(10): 96-100,

October 2021 DOI: https://doi.org/10.37547/pedagogics-crjp-02-10-18

ISSN 2767-3278

(C)2021 Master Journals

Crossref doi) 81 Google

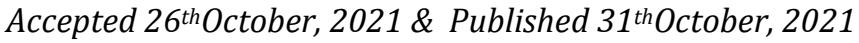

scientific and methodological conference

(with international participation);

Orenburg State University. - Orenburg:

OOO IPK "University", 2014. - C. 2378-

2383 